\title{
c-myc Oncogene gene dosage, serum CEA and CA-15.3 antigen levels, and cellular DNA values in relation to ex vivo chemosensitivity of primary human breast cancer ${ }^{\text {tᄎ }}$
}

\author{
Bogdan Falkiewicz, ${ }^{1,2 凶}$, Claus M. Schlotter ${ }^{3}$, Ulrich Bosse ${ }^{4}$, Krzysztof Bielawski $^{1}$ \\ and Ulf Vogt ${ }^{5}$
}

${ }^{1}$ Molecular Diagnostics Division, Faculty of Biotechnology, University of Gdańsk and Medical University of Gdańsk, Poland; ${ }^{2}$ Faculty of Chemistry, University of Gdańsk, Poland;

${ }^{3}$ Department of Obstetrics/Gynecology, St. Elisabeth Hospital, Ibbenbüren, Germany;

${ }^{4}$ Institute of Pathology, Osnabrück, Germany; ${ }^{5}$ European Laboratory Association Section Ibbenbüren, Ibbenbüren, Germany

Received: 25 October, 1999

Key words: breast cancer, antitumor drug screening assays, cultured tumor cells, antineoplastic agents, drug resistance, oncogenes

\begin{abstract}
A pilot study on relationships of selected molecular factors (c-myc oncogene average gene copy numbers (AGCN); serum CEA and CA 15.3 antigen levels; tumor cells' DNA values), to the ex vivo chemosensitivity of primary female human breast cancer in a modified adenosine triphosphate cell viability chemosensitivity assay (ATP-CVA),
\end{abstract}

\footnotetext{
$\overline{{ }^{\star}}$ Presented at the $7^{\text {th }}$ International Symposium on Molecular Aspects of Chemotherapy, September 8-11, 1999, Gdańsk, Poland.

The authors gratefully acknowledge the support from the European Laboratory Association Section Ibbenbüren, Germany.

${ }^{{ }}$To whom correspondence should be addressed: Bogdan Falkiewicz, phone/fax (48 22) 583012807 , e-mail: bogdanf@chemik.chem.univ.gda.pl; or Ulf Vogt, ELA Section Ibbenbüren, Roggenkampstr. 10, 49477 Ibbenbüren, Germany; phone: (49) 054516 056; fax: (49) 054516 057;

e-mail: DRUVOGT@t-online.de
}

Abbreviations: AGCN, average gene copy number; AUC, area under chemoresponse curve; ATP-CVA, ATP cell viability assay; CA-15.3, carbohydrate antigen 15.3; CEA, carcinoembryonic antigen; CMF, combination of cyclophosphamide, metotrexate and 5-fluorouracil; ddPCR, double differential polymerase chain reaction; FEC, combination of 5-fluorouracil, epirubicin, and cyclophosphamide; $H B B$, human $\beta$-globin-encoding gene; $p$, probability of error that is involved in accepting our observed result as valid; PE, combination of paclitaxel and epirubicin; PMi, combination of paclitaxel and mitoxantrone; SOD2, gene encoding human superoxide dismutase; TDC, test drug concentration; TGI, total growth inhibition. 
was performed. Four drug combinations were tested. A group of 75 cases of female primary breast cancer was assessed. Numerous correlations were found among molecular factors tested but none, with the exception of tumor grading, of these reflected ex vivo chemosensitivity of tumors tested. The results suggest that the parameters tested may not be important factors related to adjuvant chemoresponsiveness of primary human breast cancer to tested drug combinations.

Breast cancer is still a leading cause of death among women concerning the neoplasmic disease around the world. Patients with operable breast cancer are primarily treated by surgery, and then by postoperative hormonal therapy, radiotherapy and/or chemotherapy, with the exception of patients with early-stage disease. The necessity of choosing a good adjuvant treatment for breast cancer patients, e.g. an effective chemotherapy regimen, is one of the key problems in the therapy. One of the ways of selecting the proper treatment is the analysis of clinicopathological data, as well as the status of some molecular factors known as having a predictive value in breast cancer, e.g. status of erbB-2 oncogene and/or its product (recently discussed by Clark, 1998). The other factors studied in the case of breast cancer (without established predictive value, however), are other oncogenes [e.g. myc family (Ryan \& Birnie, 1996)] and serum markers, e.g. CEA and CA-15.3 antigens which, used in combination, correlate to breast cancer dissemination and may be useful markers of the effectiveness of therapy used, as well as markers of disease relapses (Molina \& Gion, 1998; Robertson et al., 1999).

It is currently accepted that cancer patients' clinical and histopathological evaluation does not provide sufficient information as regards the response to chemotherapy. Drug selection for individual patients is usually based on reported response rates for clinical trials (so-called empiric treatment), but not on ex vivo individualized chemosensitivity assays. The response rates are usually better after treatment with the ex vivo selected chemotherapy regimens than with empiric ones, however, only one third of patients entered in prospective trials of ex vivo chemosensitivity test- ing were treated with an ex vivo best regimen, as reviewed by Cortazar \& Johnson (1999).

In, at least, some cancer patients, more effective clinical response to chemotherapy may be achieved by selecting the most active drugs on the basis of ex vivo chemosensitivity test results for individual patients (Zabel et al., 1992; 1997; Cree \& Kurbacher, 1997; Cortazar \& Johnson, 1999; Kurbacher et al., 1999). One of the ex vivo assays widely used in prediction of chemotherapy response, or in vitro drug testing in a variety of cancers, is the adenosine triphosphate cell viability chemosensitivity assay (ATP-CVA) and its modifications (Cree \& Kurbacher, 1997; Falkiewicz \& Vogt, 1999). It has a high evaluability rate and its results are independent of presence of non-cancerous cells in specimens evaluated (Cree \& Kurbacher, 1997; Falkiewicz \& Vogt, 1999). ATP-CVA is individually able to detect the majority of patients with in vivo poor or good response to chemotherapy; its sensitivity appears to be more than $85 \%$ and its specificity not less than $80 \%$, with the true positive predictive value of more than $92 \%$ and true negative predictive value of more than $70 \%$ (Cree \& Kurbacher, 1997; De Vita, 1997; Falkiewicz \& Vogt, 1999).

As we hypothesize, even better results may be obtained when the ex vivo chemosensitivity assay will be combined with assessment of molecular factors with established or probable predictive value in individual patients with cancer. Therefore, we performed a preliminary study on the correlation of selected molecular factors [c-myc oncogene average gene copy numbers (AGCN); serum CEA and CA-15.3 antigen levels; tumor cells' DNA values] with the ex vivo chemosensitivity of ovarian cancer in the modified ATP-CVA. 


\section{PATIENTS, MATERIALS AND METHODS}

A group of 75 female patients with primary, histologically confirmed, invasive breast cancer, diagnosed and treated in the Department of Obstetrics/Gynecology of the St. Elisabeth Hospital, Ibbenbüren, was assessed. The mean age of patients was $57.2 \pm 11.4$ years (mean \pm S.D., range 34-81 years). The tumors assessed were classified according to the TNM classification of breast cancer. Tumor staging was: pT1: 47\%, pT2: 39\%, pT3: 5\%, pT4: $9 \%$. Tumor grading was as follows: G1: 4\%, G2: $40 \%$, G3 or G4: $56 \%$. Nodal status classification was: pN0: $65 \%, \mathrm{pN} 1: 32 \%, \mathrm{pN} 2: 1 \%$, unknown nodal status: $1 \%$. One patient had detectable metastasis (pM0: 99\%, pM1: 1\%); $20 \%$ of patients were premenopausal, $7 \%$ peripausal, $73 \%$ postmenopausal.

Statistical analyses were performed using Statistica for Windows 4.3 software (Statsoft Inc., OK, USA).

c-myc Oncogene average gene copy numbers (AGCN). The AGCNs were determined using double differential polymerase chain reaction (ddPCR). The general ddPCR reaction conditions, reproducibility and clinical usefulness have been described elsewhere (Brandt et al., 1994; 1995a; 1995b), and we used the ddPCR and electrophoresis conditions exactly as previously described (Vogt et al., 1998a). Primers for SOD2 and HBB (Brandt et al., 1995a), and for c-myc (Beckmann et al., 1999) fragments amplification have been described previously.

Serum carcinoembryonic antigen (CEA) and carbohydrate antigen 15.3 (CA-15.3). The protein concentrations in serum were determined using commercially available CEA and CA-15.3 enzyme-linked immunosorbent assays (Abbott), in accordance with the manufacturer's instructions.

DNA values. Tumor tissue was cut up with a scalpel to $1 \mathrm{ml}$ of Partec HR-A solution (Lysing solution, Partec, Germany), then in- cubated for $10 \mathrm{~min}$ on a shaker board at room temperature. The cell suspension obtained was filtered through a $50 \mu \mathrm{m}$ nylon mesh, $3 \mathrm{ml}$ of Partec HR-B solution (Partec, Germany) was added, and the solution was incubated for $10 \mathrm{~min}$ at room temperature (DAPI-Staining). Analysis was performed directly with the Partec PAS Flow-Cytometry Analyzer using the HBO-Lamp excitation and Modfit or DPAC-Software for Cell Cycle Analysis and Ploidy Determination. The diploid region was defined as a DNA index from 0.95 to 1.05 and the tetraploid region as being from 1.9 to 2.1.

Adenosine triphosphate cell viability chemosensitivity assay (ATP-CVA). For ATP-CVA, a slightly modified method of Andreotti et al. was used (1994; 1995). Fresh breast cancer tissue specimens were treated as described by Vogt et al. (1999a). Therapeutic drug preparations from commercial sources were stored and used before expiration dates according to the manufacturer's instructions. Four drug combinations were tested: 1 - cyclophosphamide/metotrexate/ 5-fluorouracil (CMF), 62 cancer cell cultures were tested; 2 - 5-fluorouracil/epirubicin/ cyclophosphamide (FEC), 65 cancer cell cultures were tested; 3 - paclitaxel/epirubicin (PE), 67 cancer cell cultures were tested; $4-$ paclitaxel/mitoxantrone (PMi), 47 cancer cell cultures were tested. Cyclophosphamide was used in all cases as its active metabolite, 4-hydroxycyclophosphamide. The drugs were used in six dilutions, corresponding to $200 \%$, $100 \%, 50 \%, 25 \%, 12.5 \%$ and $6.25 \%$ of each drug standard test drug concentration (TDC). 100\% TDC values used were as follows: 4-hydroxycyclophosphamide $3.0 \mu \mathrm{g} / \mathrm{ml}$, metotrexate 2.8 $\mu \mathrm{g} / \mathrm{ml}$, 5-fluorouracil $22.5 \mu \mathrm{g} / \mathrm{ml}$, epirubicin $0.5 \mu \mathrm{g} / \mathrm{ml}$, paclitaxel $13.6 \mu \mathrm{g} / \mathrm{ml}$, mitoxantrone $0.65 \mu \mathrm{g} / \mathrm{ml}$ ) (Andreotti et al., 1994; 1995; Kurbacher et al., 1996a). Each measurement was performed in triplicate. Percentages of total growth inhibition (TGI) were calculated according to the formula: $1-(\mathrm{MR}-\mathrm{MI}) /(\mathrm{MO}-\mathrm{MI}) \times 100=\% \mathrm{TGI}$; where: 
$\mathrm{MR}=$ mean counts for replicate test drug cultures; $\mathrm{MI}=$ mean counts for maximum inhibition control cultures; $\mathrm{MO}=$ mean counts for no inhibition control cultures. Areas under response curves (AUC) values for percentage tumor growth inhibition $v s$ test drug concentration were calculated using the trapezoidal rule.

\section{RESULTS AND DISCUSSION}

The descriptive results of the determination of selected molecular factors in the patients studied are presented in Table 1. Some interesting statistically significant relationships
2.0) (Berns et al., 1995). A correlation between $c-m y c$ amplification status and patients' age was found ( $p=0.047$ in Mann-Whitney U test; c-myc AGCN correlation with patients' age: $p=0.035$ in Spearman rank order correlation, Spearman $R=0.24$ ). This result is the opposite of that obtained by us in a study of ovarian cancer (Vogt et al., accompanying paper) and was not known to us from published data. We also found a negative correlation between $c$-myc amplification status and fraction of cells in $\mathrm{G}_{0} \mathrm{G}_{1}$ phase ( $p=0.044$ in Mann-Whitney $\mathrm{U}$ test; c-myc AGCN correlation with the $\mathrm{G}_{0} \mathrm{G}_{1}$ cell fraction: $p=0.014$ in Spearman rank order correlation, Spearman $R=-0.30$ ) and a positive correlation with the proportion of

Table 1. Descriptive statistics of the molecular factors status in the patients studied

\begin{tabular}{lrrrrr}
\hline Factor & Mean & \multicolumn{1}{c}{ S.D. } & Median & Minimum & Maximum \\
\hline c-myc AGCN & 2.24 & 2.15 & 1.42 & 0.00 & 15.32 \\
CEA & 2.57 & 6.277 & 0.95 & 0.40 & 34.00 \\
CA-15.3 & 23.47 & 25.69 & 16.70 & 6.20 & 141.90 \\
DNA index & 1.48 & 0.45 & 1.52 & 1.00 & 3.12 \\
Proportion of cells in $\mathrm{S}$ phase (\%) & 10.77 & 8.63 & 8.30 & 1.00 & 37.68 \\
Proportion of cells in $\mathrm{G}_{0} / \mathrm{G}_{1}$ phase (\%) & 80.57 & 9.40 & 81.24 & 54.40 & 96.24 \\
Proportion of cells in $\mathrm{G}_{2} \mathrm{M}$ phase (\%) & 9.51 & 5.62 & 8.16 & 0.30 & 27.62 \\
\hline
\end{tabular}

For details see Methods

among the patients' and tumor parameters were found and summarized in Table 2.

The c-myc gene amplification determined by ddPCR was found in 24 cases (32.0\%) (according to the published cut-off value of AGCN > cells in S phase ( $p=0.004$ in Mann-Whitney $\mathrm{U}$ test; c-myc AGCN correlation with the $\mathrm{S}$ phase cell fraction: $p=0.012$ in Spearman rank order correlation, Spearman $R=0.29$ ), but not with DNA index ( $p=0.96$ in Mann-Whitney U

Table 2. Some significant relationships ( $p$ values) between the patients' parameters, parameters of tumors, and status of molecular factors

\begin{tabular}{ll}
\hline Relationships analysed & $p$ value \\
\hline Tumor grading \& patients' age & $0.039^{\mathrm{a}}$ \\
Tumor grading \& CEA level & $0.046^{\mathrm{b}}$ \\
Tumor grading \& DNA index & $0.015^{\mathrm{a}}$ \\
Tumor grading \& proportion of cells in $\mathrm{G}_{0} \mathrm{G}_{1}$ phase & $0.043^{\mathrm{a}}$ \\
Tumor grading \& proportion of cells in $\mathrm{S}$ phase & $0.017^{\mathrm{a}}$ \\
\hline
\end{tabular}

${ }^{a}$ Kruskal-Wallis ANOVA test; ${ }^{b}$ median test 
test; c-myc AGCN correlation with DNA index: $p=0.82$ in Spearman rank order correlation). What one may suspect is that the fraction of cells in $\mathrm{G}_{0} \mathrm{G}_{1}$ phase significantly negatively correlates with their fraction in $S$ phase or in $\mathrm{G}_{2} \mathrm{M}$ phase, as well as with DNA index; DNA index correlates positively with the fraction of cells in $\mathrm{S}$ phase.

In ATP-CVA, all 75 tumors tested gave the in vitro cultures (100\%). Chemoresponse ex vivo of the tumors assessed was not affected by the molecular parameters tested. However, tumor relation between areas under chemoresponse curves (AUC) obtained in ATP-CVA and other factors tested are shown in Table 3.

The most effective drug regimen in the study was the PMi combination, giving the mean AUC of 17091, slightly less effective was the $\mathrm{PE}$ combination, giving the mean AUC of 16332, a worse regimen was the FEC combination, giving the mean AUC of 14528. The least effective regimen was the CMF combination, giving the mean AUC of 10735. In the study, all the ex vivo chemosensitivity results

Table 3. Relationships ( $p$ values) of AUC for four drug regimens tested to $c-m y c$ oncogene average gene copy numbers (AGCN), serum CEA and CA-15.3 antigen levels, and tumor cells' DNA values

\begin{tabular}{lllll}
\hline Factor analysed & \multicolumn{3}{c}{ Drug regimen } \\
\hline & CMF & FEC & PE & PMi \\
c-myc AGCN & $0.86^{\mathrm{b}}$ & $0.92^{\mathrm{b}}$ & $0.44^{\mathrm{b}}$ & $0.50^{\mathrm{b}}$ \\
c-myc amplification $^{\mathrm{a}}$ & $0.37^{\mathrm{c}}$ & $0.55^{\mathrm{c}}$ & $0.42^{\mathrm{c}}$ & $0.91^{\mathrm{c}}$ \\
CEA & $0.32^{\mathrm{b}}$ & $0.78^{\mathrm{b}}$ & $0.96^{\mathrm{b}}$ & $0.70^{\mathrm{b}}$ \\
CA-15.3 & $0.43^{\mathrm{b}}$ & $0.85^{\mathrm{b}}$ & $0.51^{\mathrm{b}}$ & $0.86^{\mathrm{b}}$ \\
DNA index & $0.81^{\mathrm{b}}$ & $0.31^{\mathrm{b}}$ & $0.25^{\mathrm{b}}$ & $0.71^{\mathrm{b}}$ \\
Proportion of cells in S phase & $0.29^{\mathrm{b}}$ & $0.80^{\mathrm{b}}$ & $0.19^{\mathrm{b}}$ & $0.95^{\mathrm{b}}$ \\
Proportion of cells in $\mathrm{G}_{0} / \mathrm{G}_{1}$ phase & $0.50^{\mathrm{b}}$ & $0.77^{\mathrm{b}}$ & $0.26^{\mathrm{b}}$ & $0.56^{\mathrm{b}}$ \\
Proportion of cells in $\mathrm{G}_{2} \mathrm{M}^{\mathrm{b}}$ phase & $0.63^{\mathrm{b}}$ & $0.49^{\mathrm{b}}$ & $0.34^{\mathrm{b}}$ & $0.57^{\mathrm{b}}$ \\
Tumor grading & $0.77^{\mathrm{d}}$ & $\underline{\mathbf{0 . 0 3}}^{\mathrm{d}}$ & $\underline{\mathbf{0 . 0 1}}^{\mathrm{d}}$ & $\mathbf{0 . 2 1 ^ { \mathrm { d } }}$ \\
pT classification $^{\mathrm{d}}$ & $0.40^{\mathrm{d}}$ & $0.98^{\mathrm{d}}$ & $0.78^{\mathrm{d}}$ & $0.75^{\mathrm{d}}$ \\
Patients' menopausal status & $0.27^{\mathrm{d}}$ & $0.31^{\mathrm{d}}$ & $0.74^{\mathrm{d}}$ & $0.89^{\mathrm{d}}$ \\
\hline
\end{tabular}

${ }^{\mathrm{a}}$ AGCN > 2 according to Berns et al. (1995); ${ }^{\mathrm{b}}$ Spearman rank order correlation; ${ }^{\mathrm{c}}$ Mann-Whitney U test; ${ }^{\mathrm{d}}$ Kruskal-Wallis ANOVA test

grading is the single factor found to significantly influence the ex vivo chemosensitivity of cancerous cells, but not in every drug regimen. The results of statistical analysis of cor- (expressed as AUCs) correlate strictly with each other (Table 4), despite the reported great variability in the effectivity of single drugs and drug combinations in breast cancer

Table 4. Relationships ( $p$ values) between AUC and four drug regimens tested

\begin{tabular}{|c|c|c|c|c|}
\hline Drug regimen & $\mathrm{CMF}$ & FEC & $\mathrm{PE}$ & $\mathrm{PMi}$ \\
\hline $\mathrm{CMF}$ & - & $0.00001^{a}$ & $\underline{0.001}^{\mathrm{a}}$ & $0_{0.001}^{a}$ \\
\hline FEC & $0.00001^{\mathrm{a}}$ & - & $<0.000000^{a}$ & $0.000001^{a}$ \\
\hline $\mathrm{PE}$ & $0.001^{\mathrm{a}}$ & $\leq 0.000000^{\mathrm{a}}$ & - & $<0.000000^{a}$ \\
\hline PMi & $\underline{0.001}^{\mathrm{a}}$ & $0.000001^{\mathrm{a}}$ & $<0.000000^{\mathrm{a}}$ & - \\
\hline
\end{tabular}

${ }^{\mathrm{a}}$ Spearman rank order correlation 
specimens tested ex vivo (Kurbacher et al., 1996b).

Various modifications of ATP-CVA have been applied in some studies for the ex vivo prediction of breast cancer patients' response to chemotherapy (Hunter et al., 1993; Petty et al., 1994; Köchli et al., 1993; 1995; Cree et al., 1996; Kurbacher et al., 1996a; 1996b; 1999), or for chemosensitivity testing in breast cancer cell lines (several examples). We recently tested the combinations of ATP-CVA with cellular DNA parameters, oncogenes' gene dosage abberations and/or overexpression in a primary non-small cell lung cancer (Vogt et al., 1998b) and ovarian cancer (Vogt et al., 1999b). To the best of our knowledge, prior to our recent studies (Falkiewicz et al., 1999; Schlotter et al., 1999), ATP-CVA results in breast cancer have only once been correlated with molecular factors known as having a prognostic or predictive value in breast cancer, namely with p53 gene product expression, in a study which demonstrated a correlation between p53 protein expression and chemosensitivity of human breast cancer specimens (Petty et al., 1994).

In conclusion, the lack of correlation of $c-m y c$ AGCN, c-myc amplification status, serum CEA and CA-15.3 antigen levels, or proportions of cells in various cell cycle phases with chemosensitivity to all tested drug combinations, found in the present study, may suggest that the parameters tested may not be important factors related to adjuvant chemoresponsiveness of primary human breast cancer to tested drug combinations. In order to obtain useful and valuable results of combined testing we recently analysed the combination of other molecular factors (namely $e r b B$ oncogene family gene dosages and $e r b B-2$ expression) with ATP-CVA in the breast cancer (Schlotter et al., 1999). The results of the study are promising and suggest that erbB-2 expression (but not erbB family gene aberrations), may be effectively combined in ex vivo chemoresponsiveness prediction of primary human breast cancer, but this preliminary suggestion awaits further clinical confirmation.

\section{R E F E R E N C E S}

Andreotti, P.E., Linder, D., Hartmann, D.M., Cree, I.A., Pazzagli, M. \& Bruckner, H.W. (1994) TCA-100 tumour chemosensitivity assay: Differences in sensitivity between cultured tumour cell lines and clinical studies. $J$. Biolumin. Chemilumin. 9, 373-378.

Andreotti, P.E., Cree, I.A., Kurbacher, C.M., Hartmann, D.M., Linder, D., Harel, G., Gleiberman, I., Caruso, P.A., Ricks, S.H., Untch, M., Sartori, C. \& Bruckner, H.W. (1995) Chemosensitivity testing of human tumors using a microplate adenosine triphosphate luminescence assay: Clinical correlation for cisplatin resistance of ovarian carcinoma. Cancer Res. 55, 5276-5282.

Beckmann, A., Vogt, U., Huda, N., Zänker, K.S. \& Brandt, B.H. (1999) Direct-double-differential PCR for gene dosage quantification of c-myc. Clin. Chem. 45, 141-143.

Berns, E.M.J.J., Foekens, J.A., Van Staveren, I.L., Van Putten, W.L.J., De Koning, H.Y.W.C.M., Portengen, H. \& Klijn, J.G.M. (1995) Oncogene amplification and prognosis in breast cancer: Relationship with systemic treatment. Gene 159, 11-18.

Brandt, B., Vogt, U., Griwatz, C., Harms, F., Bosse, U. \& Zänker, K.S. (1994) Detection of amplified oncogenes by differential polymerase chain reaction; in Methods in DNA Amplification (Rolfs, A., Weber-Rolfs, I. \& Finckh, U., eds.) pp. 55-64, Plenum Press, New York.

Brandt, B., Vogt, U., Harms, F., Bosse, U., Zänker, K.S. \& Assmann, G. (1995a) Double-differential PCR for gene dosage estimation of erbB oncogenes in benign and cancer tissues and comparison to cellular DNA content. Gene 159, 29-34.

Brandt, B., Vogt, U., Schlotter, C.M., Jackisch, C., Werkmeister, R., Thomas, M., Von Eiff, M., Bosse, U., Assmann, G. \& Zänker, K.S. (1995b) Prognostic relevance of aberrations in the erbB oncogenes from breast, ovarian, oral and 
lung cancers: Double-differential polymerase chain reaction (ddPCR) for clinical diagnosis. Gene 159, 35-42.

Clark, G.M. (1998) Should selection of adjuvant chemotherapy for patients with breast cancer be based on erbB-2 status? J. Natl. Cancer Inst. 90, 1320-1321.

Cortazar, P. \& Johnson, B.E. (1999) Review of the efficacy of individualized chemotherapy selected by in vitro drug sensitivity testing for patients with cancer. J. Clin. Oncol. 17, 16251631.

Cree, I.A., Kurbacher, C.M., Untch, M., Sutherland, L.A., Hunter, E.M., Subedi, A.M.C., James, E.A., Dewar, J.A., Preece, P.E., Andreotti, P.E. \& Bruckner, H.W. (1996) Correlation of the clinical response to chemotherapy in breast cancer with ex vivo chemosensitivity. Anti-Cancer Drugs 7, 630-635.

Cree, I.A. \& Kurbacher, C.M. (1997) Individualizing chemotherapy for solid tumors - is there any alternative? Anti-Cancer Drugs 8, 541-548.

De Vita, V.T., Jr. (1997) Principles of cancer management: Chemotherapy; in Cancer: Principles and Practice of Oncology (De Vita, V.T., Jr., Hellman, S. \& Rosenberg, S.A., eds.) pp. 333347, Lippincott-Raven Publishers, Philadelphia.

Falkiewicz, B. \& Vogt, U. (1999) In vitro prediction of cancer patients' response to chemotherapy, in Breast Cancer (Bonk, U. et al., ed.). Ullstein Medical Verlag Wiesbaden, Springer (in press).

Falkiewicz, B., Schlotter, C.M., Bosse, U., Bielawski, K., Podhajska, A.J. \& Vogt, U. (1999) Chemosensitivity of primary human breast cancers in ATP-CVA assay in relationship to their oncogene status. 7th International Symposium on Molecular Aspects of Chemotherapy, 8-11 September 1999, Gdańsk, Poland. Abstract Book, p. 94.

Hunter, E.M., Sutherland, L.A., Cree, I.A., Dewar, J.A., Preece, P.E., Wood, R.A.B., Linder, D. \& Andreotti, P.E. (1993) Heterogeneity of chemosensitivity in human breast carcinoma: Use of an adenosine triphosphate (ATP) chemiluminescence assay. Eur. J. Surg. Oncol. 19, 242-249.

Köchli, O.R., Avner, B.P., Sevin, B.-U., Avner, B., Parras, J.P., Robinson, D.S. \& Averette, H.E. (1993) Application of the adenosine triphosphate-cell viability assay in human breast cancer chemosensitivity testing: A report on the first results. J. Surg. Oncol. 54, 119-125.

Köchli, O.R., Sevin, B.-U., Schaer, G. \& Haller, U. (1995) Application of the adenosine triphosphate-cell viability assay for pretherapeutic chemosensitivity testing in breast cancer. Geburtsh. Frauenheilk. 55, 7-16 (in German).

Kurbacher, C.M., Mallmann, P., Kurbacher, J.A., Hubner, H. \& Krebs, D. (1996a) Chemosensitivity testing in gynaecological oncology: Experiences with an ATP-bioluminescence assay. Geburtsh. Frauenheilk. 56, 70-78 (in German).

Kurbacher, C.M., Cree, I.A., Brenne, U., Bruckner, H.W., Kurbacher, J.A., Mallmann, P., Andreotti, P.E. \& Krebs, D. (1996b) Heterogeneity of in vitro chemosensitivity in perioperative breast cancer cells to mitoxantrone versus doxorubicin evaluated by a microplate ATP bioluminescence assay. Breast Cancer Res. Treat. 41, 161-170.

Kurbacher, C.M., Bruckner, H.W., Cree, I.A., Andreotti, P.A. \& Janat, M.M. (1999) A prospective clinical trial on individualized chemotherapy for recurrent ovarian cancer selected by the ex vivo ATP tumor chemosensitivity assay. Proc. Am. Soc. Clin. Oncol. 18, 1384 (abstract).

Molina, R. \& Gion, M. (1998) Use of blood tumour markers in the detection of recurrent breast cancer. The Breast 7, 187-189.

Petty, R.D., Cree, I.A., Sutherland, L.A., Hunter, E.M., Lane, D.P., Preece, P.E. \& Andreotti, P.E. (1994) Expression of the p53 tumour suppressor gene product is a determinant of chemosensitivity. Biochem. Biophys. Res. Commun. 199, 264-270.

Robertson, J.F.R., Jaeger, W., Szymendera, J.J., Selby, C., Coleman, R., Howell, A., Winstanley, J., Jonssen, P.E., Bombardieri, E., Sainsbury, J.R.C., Gronberg, H., Kumpulainen, E., Blamey, R.W. and Europen Group for Serum 
Tumour Markers in Breast Cancer (1999) The objective measurement of remission and progression in metastatic breast cancer by use of serum tumour markers. Eur. J. Cancer 35, 47-53.

Ryan, K.M. \& Birnie, G.D. (1996) Myc oncogenes: the enigmatic family. Biochem. J. 314, $713-721$.

Schlotter, C.M., Bosse, U., Falkiewicz, B., Bielawski, K. \& Vogt, U. (1999) Correlation of erbB oncogene family gene dosages and erbB-2 expression to in vitro chemosensitivity of primary human breast cancers. Proc. Am. Soc. Clin. Oncol. 18, 409 (abstract).

Vogt, U., Bielawski, K., Schlotter, C.M., Bosse, U., Falkiewicz, B. \& Podhajska, A.J. (1998a) Amplification of erbB-4 oncogene occurs less frequently than that of erbB-2 in primary human breast cancer. Gene 223, 375-380.

Vogt, U., Striehn, E., Bosse, U. \& Klinke, F. (1998b) Is the combination of ATP cell viability chemosensitivity assay (ATP-CVA) and molecular prognostic factors able to detect NSCLC patients with good or poor response to chemotherapy? Thorac Cardiovasc. Surg. 46 (suppl. 1), 225 (abstract).
Vogt, U., Striehn, E., Bosse, U., Klinke, F. \& Falkiewicz, B. (1999a) Lack of squamous cell lung carcinoma in vitro chemosensitivity to various drug regimens in the adenosine triphosphate cell viability chemosensitivity assay. Acta Biochim. Polon. 46, 299-302.

Vogt, U., Bielawski, K., Schlotter, C.M., Bosse, U., Podhajska, A.J. \& Falkiewicz, B. (1999b). Relationship of $c-m y c$ and $e r b B$ oncogene family gene aberrations and other molecular factors to ex vivo chemosensitivity of ovarian cancer in the modified ATP-chemosensitivity assay. 7th International Symposium on Molecular Aspects of Chemotherapy, 8-11 September 1999, Gdańsk, Poland. Abstract book, p. 95.

Zabel, M., Kaczmarek, A., Łukianow, R., Ramlau, R. \& Górny, A. (1992) Testowanie wrażliwości komórek nowotworowych na cytostatyki w warunkach hodowli komórkowej. Nowotwory 42, 187-192 (in Polish).

Zabel, M., Kaczmarek, A., Rozmiarek, A. \& Markowska, J. (1997) Test wrażliwości komórek nowotworowych na cytostatyki in vitro, a efekt kliniczny. Wspótcz. Onkol. 2, 17-19 (in Polish). 